\title{
A case of late infantile neuronal ceroid lipofuscinosis type 5
}

\author{
*Nimantha Dhananjaya Vithanage ${ }^{1}$, Wijitha Kumari Yapa ${ }^{2}$, Eresha Jasinge ${ }^{2}$, Pyara Ratnayake ${ }^{2}$, Lakmali \\ Kandegedara Mihirani², Nilupuli Sumanasekara ${ }^{2}$, Christopher Luckshanth Anandarajah ${ }^{2}$
}

Sri Lanka Journal of Child Health, 2021; 50(2): 353-355

DOI: http://dx.doi.org/10.4038/sljch.v50i2.9588

(Key words: Neuronal ceroid lipofuscinosis, late infantile, NCL, developmental regression)

\section{Introduction}

Neuronal Ceroid Lipofuscinosis (NCL) is a rare neurodegenerative disorder due to defective lysosomal storage causing intracellular accumulation of ceroid and lipofuscin ${ }^{1}$. This disorder is characterized by progressive visual loss, deterioration of motor and higher functions and early death. NCL is classified into 9 sub-types according to genetic mutations ${ }^{1}$. NCL is also classified according to the age of onset. We report a case of late infantile form of NCL sub classified as NCL type 5.

\section{Case report}

A 12-year-old Sinhalese girl presented with worsening of generalized tonic-clonic and myoclonic convulsions. She was adopted in her early neonatal period. Adopted parents are not aware of consanguinity, birth complications or neonatal insults. Parents had concerns about speech, finemotor and cognitive functions from late infancy. Gross motor abilities were relatively spared initially. She was able to walk and run on her own in the preschool age with some clumsiness. At primary school age she was only able to copy a circle and communicate in 2-3 word sentences indicating severe cognitive and fine motor delay. She dropped out of school from grade 1 due to poor school performance.

Since 7 years of age child had been having recurrent convulsions, suggestive of drop attacks and generalized tonic-clonic convulsions. Initially there were 1-2 episodes per day. Her developmental mile

${ }^{1}$ Teaching hospital Karapitiya, Sri Lanka, ${ }^{2}$ Lady Ridgeway Hospital for Children, Colombo, Sri Lanka.

*Correspondence: nimanthadvg@gmail.com

https://orcid.org/0000-0002-1209-9402 (Keceived on 10 July 2020: Accepted after revision on 21 August 2020)

The authors declare that there are no conflicts of interest

Personal funding was used for the project.

Open Access Article published under the Creative

Commons Attribution CC-BY (c) (i) License stones were regressing markedly since this age. She was initially investigated at the local hospital and then transferred to a teaching hospital. With the progressive regression of vision, speech and motor functions, child was lost to medical follow up since parents had sought alternative medication.

Examination findings revealed a bed bound child, Gross Motor Function Classification System (GMFCS) grade 4, with microcephaly (occipitofrontal circumference $49 \mathrm{~cm}<5^{\text {th }}$ centile) and impaired higher functions. She was not able to fix and follow or appreciate sharp light. Pigmentary retinopathy with optic disc pallor was noted on funduscopic examination. She was unable to communicate effectively with her mother. Other cranial nerves were normal. Some stereotypic movements involving both upper and lower limbs were noted. Muscle power was grade 4. Tone was normal and reflexes were brisk. Abdominal examination revealed no organomegaly.

There were no significant derangements in haematological, biochemical and metabolic investigations except for a marginally elevated plasma ammonia level which was probably caused by valproate treatment (Table 1). Contrast enhanced computed tomography (CECT) of brain revealed diffuse brain atrophy involving cerebrum, cerebellum and brain stem.

Clinical suspicion of NCL was made based on the history of developmental regression, myoclonic convulsions, and impaired vision with pigmentary retinopathy, optic disc pallor and cerebral / cerebellar atrophy. The absence of organomegaly and normal serum lactate level were useful in excluding other differential diagnoses such as mitochondrial disorders. The genetic studies were done at "CENTOGENE", the rare disease company, and revealed a homozygous likely pathogenic variant in CLN5 gene. It is a nonsense mutation in CLN5 gene (CLN 5 variant c.621G $>$ A p. (Trp207*) which is associated with autosomal recessive NCL 5. 
Table1: Investigations carried out in the child

\begin{tabular}{|l|c|c|c|}
\hline \multicolumn{1}{|c|}{ Investigation } & Result & Normal range & Units \\
\hline Haemoglobin concentration & 13.2 & $11-14$ & $\mathrm{~g} / \mathrm{dl}$ \\
\hline Total white blood cell count & 6100 & $5000-12,000$ & $/ \mathrm{cu} \mathrm{mm}$ \\
\hline Platelet count & 346,000 & $150,000-450,000$ & $/ \mathrm{cu} \mathrm{mm}$ \\
\hline Blood urea & 2.2 & $1.8-6.4$ & $\mathrm{mmol} / \mathrm{L}$ \\
\hline Serum aspartate transaminase & 16 & $10-40$ & $\mathrm{U} / \mathrm{L}$ \\
\hline Serum alanine transaminase & 11 & $9-48$ & $\mathrm{U} / \mathrm{L}$ \\
\hline Serum uric acid & 110 & $119-327$ & $\mathrm{mg} / \mathrm{mg}$ \\
\hline Urine uric acid/creatinine & 0.34 & $0.2-0.65$ & $\mu \mathrm{mol} / \mathrm{L}$ \\
\hline Serum creatinine & 40 & $50-80$ & $\mathrm{mmol} / \mathrm{L}$ \\
\hline Serum sodium & 138 & $135-145$ & $\mathrm{mmol} / \mathrm{L}$ \\
\hline Serum potassium & 3.5 & $3.5-5.3$ & $\mathrm{mmol} / \mathrm{L}$ \\
\hline Serum calcium & 2.28 & $2.2-2.7$ & $\mathrm{mmol} / \mathrm{L}$ \\
\hline Serum cholesterol & 3.2 & $2.8-5.2$ & $\mathrm{mmol} / \mathrm{L}$ \\
\hline Plasma ammonia & 66 & $<40$ & $\mathrm{mmol} / \mathrm{L}$ \\
\hline Serum lactate & 0.02 & $0.5-2.3$ & $\mathrm{mmol} / \mathrm{L}$ \\
\hline Random blood glucose & 4.2 & $3.9-7.7$ & \\
\hline
\end{tabular}

\section{Discussion}

NCL is a heterogeneous neurodegenerative disorder that is sub-classified according to its age of onset as infantile, late infantile and juvenile. Late infantile $\mathrm{NCL}$ is the $2^{\text {nd }}$ most common $\mathrm{NCL}^{2}$. This disorder is rarely reported from Asian countries and is common in Scandinavian countries ${ }^{3}$. Late infantile NCL was first documented in 1908 by "Jansky" and further described by "Beilchowsky" in 1913 and hence is also called "Jansky Beilchowsky" type 4 .

Late infantile NCL can present from late infancy to early childhood ${ }^{1}$. Delayed speech and clumsiness in motor activity are often early signs which were the first manifestations of our patient as well ${ }^{2}$. Other early features include seizures and mental retardation which were severe enough to cause school dropout in our patient. Progressive motor dysfunction and blindness are the typical sequelae. This patient became bed bound and blind around the age of 10-11 years.

Optic disc pallor and pigmentary retinopathy are characteristic ophthalmic findings in $\mathrm{NCL}^{1}$. Brain atrophy that is marked in cerebellum is also a typical finding ${ }^{2}$. Eosinophilic inclusion bodies can be observed in skin biopsy².

The diagnosis is confirmed by genetic studies. Late infantile NCL can be caused by several gene mutations that are transmitted by autosomal recessive inheritance. These include CLN2, CLN5, CLN6 and CLN8 genes. CLN5 type was first described in children from Finland. This type usually presents at 4-7 years with motor clumsiness as its first manifestation ${ }^{5,6}$. Our patient had CLN5 variant that creates a premature stop codon causing non sense mutation ${ }^{5,6}$. Azad $\mathrm{B}$, et al recently reported novel likely disease causing CLN5 variants in Pakistani patients with $\mathrm{NCL}^{7}$.
The outcome is usually poor in late infantile NCL. There are no definitive treatment modalities. Gene therapy and haematopoietic stem cell transplantation (HSCT) were tried as treatment modalities with poor success $^{2}$. Most succumb in adolescence. In our patient supportive care was arranged and parents were counselled regarding the poor prognosis.

\section{Acknowledgements}

We thank "Centogene", the rare disease company for performing the genetic testing free-of-charge.

\section{References}

1. Kliegman R, Geme JS, Nelson Textbook of Paediatrics. $21^{\text {st }}$ ed. 2019. pp. 3190-1.

2. Verma R, Raut TP, Tiwari N, Malhotra KP, Hussain N, Malhotra HS. Late infantile neuronal ceroid lipofuscinosis: case report with review of literature: Annals of Indian Academy of Neurology 2013; 16(2):282-5. https://doi.org/10.4103/0972-2327.112500 PMid: 23956585 PMCid: PMC3724095

3. Ko CH, Kong CK, Chow T-C, Lee Kc. Classic late infantile neuronal ceroid lipofuscinosis in a Chinese patient. Hong Kong Medical Journal 2001; 7(1):93-6.

4. Bielchowsky M. About Late infantile amaurotic familial idiocy with cerebellar symptoms. Dtsch Z Nervenheilkd 1913; 50:7-29.

5. Savukoski M, Klockars T, Holmberg V, Santavuori P, Lander ES, Peltoneri L. CLN5, a novel gene encoding a putative transmembrane protein mutated in Finnish variant late infantile neuronal ceroid 
lipofuscinosis: Nature Genetics 1998; 19: 286-8.

https://doi.org/10.1038/975

PMid: 9662406

6. Kousi M, Lehesjoki A-E, Mole SE. Update of the mutation spectrum and clinical correlations of over 360 mutations in eight genes that underlie the neuronal ceroid lipofuscinoses. Human Mutation 2012; 33(1): 42-63

https://doi.org/10.1002/humu.21624

PMid: 21990111
7. Azad B, Efthymiou S, Sultan T, Scala M, Alvi JR, Neuray C, et al. Novel likely disease-causing CLN5 variants identified in Pakistani patients with neuronal ceroid lipofuscinosis, Journal of the Neurological Sciences 2020: 414:116826

https://doi.org/10.1016/j.jns.2020.116826

PMid: 32302805 PMCid: PMC7306150 